Informasi - ISSN (p) 0126-0650; ISSN (e) 2502-3837

Vol. 50, No. 2 (2020), pp. 177-186 doi: http://doi.org/10.21831/informasi.v50i2.36847

\title{
Parenting and sharenting communication for preventing juvenile delinquency
}

\author{
Suranto Aw \\ Department of Communication Science, Faculty of Social Sciences \\ Universitas Negeri Yogyakarta, Indonesia \\ suranto@uny.ac.id \\ Pratiwi Wahyu Widiarti \\ Department of Communication Science, Faculty of Social Sciences \\ Universitas Negeri Yogyakarta, Indonesia \\ pratiwi_ww@uny.ac.id

\section{Benni Setiawan} \\ Department of Communication Science, Faculty of Social Sciences \\ Universitas Negeri Yogyakarta, Indonesia \\ bennisetiawan@uny.ac.id
}

\section{Normah Mustaffa}

Centre for Research in Media E Communication, Faculty of Social Sciences and Humanities

Universiti Kebangsaan Malaysia, Malaysia

normahm@ukm.edu.my

\section{Mohd. Nor Shahizan Ali}

Centre for Research in Media E Communication, Faculty of Social Sciences and Humanities

Universiti Kebangsaan Malaysia, Malaysia

shahizan@ukm.edu.my

\section{Chatia Hastasari}

International Doctoral Program for Asia-Pacific Studies Social Science Faculty

National Chengchi University, Taiwan

109265507@nccu.edu.tw

Article History: Received 2020-12-02, Revised 2020-12-22, Accepted 2020-12-24 


\begin{abstract}
The focus of this research is to examine the communication techniques between parents and children in the context of parenting and giving advice (sharenting) for the prevention of children or adolescents' delinquency. The informants of this research were students, teachers, parents, and community leaders from two countries (Indonesia and Malaysia). Data were collected utilizing the focus group discussion techniques via Zoom meeting platform. Data were analyzed using interactive analysis which includes four stages, namely: data collection, data reduction, display data, and drawing a conclusion/ verification. The results show that parenting and sharenting communication are strategic forums to guide adolescents to avoid various forms of deviant behavior, especially delinquency. The communication techniques applied consist of persuasive and in certain conditions coercive communication techniques are utilized. Communication barriers include the lack of commitment of some parents in carrying out comprehensive communication.
\end{abstract}

Keywords: Communication, Parenting, Sharenting, Delinquency, Adolescence

\section{INTRODUCTION}

A number of research conducted by the educational experts (for example Sumara, Humaedi, and Santoso 2017; Muawanah, 2012; Unayah and Sabarisman 2016) note that the juvenile delinquency level in various big cities in Indonesia and Malaysia tend to increase both in its quality and quantity. In addition, there was an increase in the quality and quantity of delinquency and other deviant behaviors performed by adolescents. The juvenile delinquency including vandalism, brawls, motorbike gangs, smoking, alcoholic drinking, drugs, theft, and street children, still color the world of education in Indonesia and Malaysia (Aw., 2019). Of the 15,000 drug cases during the last two years in Indonesia, $46 \%$ of them involve students or teenagers. In 2016, there were 157 cases of student delinquency and it increased to 183 cases in 2017 (Aini, 2017). Another study reported that viewed from the location of the event, student delinquency more frequently occurred in big cities such as Jakarta, Surabaya, Semarang, and Medan. The trends of juvenile delinquency and crime which include physical violence, sexual violence and psychological violence show an increasing number from year to year. In 2015, it was recorded that 3145 adolescents aged $\leq 18$ years became criminals; it increased to 3280 and 4123 adolescents in 2018 (Central Statistics Agency, 2019). Furthermore, there were 147 brawls between students in the middle of 2019 and there were 255 cases in 2020 (National Commission for Child Protection, 2020).

The adolescence is a critical period indicated by self-discovery, high lability, turmoil, and emotional imbalance. Thus, adolescents are easily influenced by the exposure of information. Normatively, juvenile delinquency is behavior that deviates from the ethical rule contained in various sources of social norms, legal norms, and cultural values that are applied in families, schools and communities. The juvenile delinquency level can be classified as low, moderate, and high. Low level of delinquency may include violating school rules and regulations, carrying on truancy, smoking, scribbling on walls, wearing sandals at schools, having long hair, sleeping in the classroom, coloring hair and the like. Moderate delinquency is delinquency which impacts other adolescents such as bullying, fights, hate speech, and so on. Serious delinquency refers to juvenile delinquency that leads to criminal acts, such as brawls, motorcycle gangs, klithih (youth violation), illegal racing, sharp weapons misuse, alcoholic drinking, drugs misuse, assault, theft, sexual harassment, and so on.

The studies examining the causes of juvenile delinquency have identified three factors which encourage the juvenile 
delinquency, namely pressure, opportunity, and justification. Pressure deals with the urge to commit juvenile delinquency that sources from oneself (internal) and from outside of oneself (external). Internal pressure as one of the factors that causes delinquency consists of personality, emotional condition, self-esteem, and the ability to develop interpersonal relationships. Meanwhile, the external pressure which can lead to student delinquency behavior include the exposure to information from social media, peer influence, and less harmonious environmental conditions. Moreover, opportunities are chances that allow juvenile delinquency to occur. These opportunities can be in the form of lack supervision of parents in the family and teachers in schools as well as too permissive social norms in the society which may encourage juvenile delinquency. Furthermore, justification deals with attitude of justifying juvenile delinquency where people view juvenile delinquency as a natural phenomenon so that the delinquency behavior is not perceived as a wrongdoing (Suranto Aw., Hajaroh, and Hastasari 2020).

To prevent the increasing number of deviant acts like juvenile delinquency, it is necessary to strengthen the role of family communication. In this case, the family is positioned as the center of defense to prevent delinquency namely through a harmonious communication process that involves all family members. In this communication process, parents hold an important task, namely as a source of information in parenting and sharing ideas, experiences, and advice to children or what is called sharenting. Sharenting is a combination of the terms "sharing" and "parenting" (BlumRoss and Livingstone 2017) which is defined as the parent's activity of sharing information and advice in the form of good values in the social life.

\section{LITERATURE REVIEW}

The family is the main and first place for children to get education and care both from parents and other family members. Therefore, parents as communicators need to communicate harmoniously. Communication within the family should be utilized as a medium for motivating and controlling the children. Davis and Carter (2008) reveal that the role of mothers is generally better than fathers in parenting communication processes within the family. A mother has a better emotional closeness to her child because of their togetherness since the child is still in the womb.

Parenting and sharenting communication is carried out at an early age which is targeted for fulfilling the family special needs, namely instilling the values of life in children while offering mechanisms to deal with and reduce various possibilities for children's deviant behaviour which may emerge as they interact with peers (Keen, Couzens, Muspratt, \& Rodger (2010). In the process of parenting and sharenting communication, commitment is required to sustain the closeness and openness to children, and vice versa. The dimensions of closeness and openness of care seem to play an important role in empowering adolescents to act agentically through communication, provide emotional support, and encourage autonomy, which in turn can contribute to positive behaviour in adolescence (Klein, Becker, \& Štulhofer 2018).

The effectiveness of parenting communication is highly determined by parental figures as role models for children. Therefore, parents need to maintain their credibility by behaving consistently between words and actions. Besides, parents are required to understand social values which are utilized as references in performing communication and social interaction (Siibak \& Traks, 2019). The more developed communication and information technology is, the bigger external influence on adolescents will be. Their smartphones should be empowered and utilized to get useful information for supporting their education. Choi \& Lewallen (2018) suggest that parents should be aware and careful about the new phenomenon in sharenting 
communication, which is marked by the parent's excessive use of social media who share content to their children, which has increased children's digital representation on social media.

The effects of parenting and sharenting communication are the changes of cognitive, affective and behavioural experienced by the adolescents. If communication is carried out consistently and continuously, there will be an interaction, which influence each other between individuals, specifically between parents and children. In general, communication enables the communicators to convey information and influence psychological behaviour of the communicants in accordance with the expectations of the communicators (Rahmat, 2001). To achieve the communication effects desired by the communicators, it is necessary to select an approach that is most suitable to the characteristics of the communicant. Kurniawan (2018) mentions four communication approaches that can lead to changes in the behaviour of the target audience, namely conveying information, instructions, persuasion, and dialogues.

The focus of this research is revealing the effectiveness of parenting and sharenting communication as an effort to prevent juvenile delinquency. Based on several literatures, two models of communication approaches have been identified, namely: (1) a structural model which is characterized by authoritarian, one-way top-down, formal, coercive, instantaneous, do not root at the interests of the communicant; (2) the cultural model which is based on the development of community culture, family culture, and school culture, bottomup, informal, arises from awareness and commitment, rooted in everyone involved in the communication process (Asriati, 2012). Meanwhile, other theories suggest formal and non-formal communication models. Formal communication is structured, focused, and there is symbolic interaction on behalf of the institutional status of the communication actors. Meanwhile, informal communication is unstructured, the dialogue process is less rigid which can last a long time although the discussion may be unfocused. Interaction prioritizes intimacy or building an intense relationship (Sulaiman, 2013). Furthermore, Locker (2004) tends to suggest a cultural and participatory communication approach that is designed by considering social, cultural, political, legal and economic norms that originate from national culture, organizational culture and personal culture.

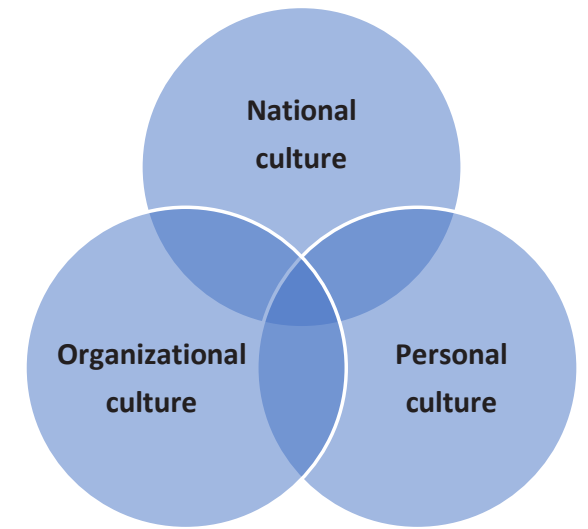

Figure 1: Sources of value (Kitty O. Locker, 2004)

Through parenting and sharenting communication, it is expected that juvenile delinquency acts can be prevented. This prevention effort has important meaning for the future of teenagers. Unayah \& Sabarisman (2016) explain the results of their analysis on the juvenile delinquency phenomenon where recently people have been shocked by the frequent criminal acts occurred in various areas, especially in urban areas. It is undeniable that the criminal acts that occurred in several areas were committed by teenagers, who initially were just ordinary juvenile delinquencies. However, due to the current era development, juvenile delinquency has shown a shift in its level that leads to criminal acts, such as stealing, fighting, robbing, raping and even killing.

The family environment is the primary and first environment for youth. In a nuclear family, the first people who communicate with adolescents are their parents. Through parents, children begin to recognize values which guide their attitudes and actions. Education in the family has a very important function. Communication within the family functions to develop personality and instill norms that include courtesy, respect for 
parents, respect forothers, perform discipline, and so on. Law No. 4 Year 1999 regarding Child Welfare states, "Parents are the first figure who have responsibility to realize children's welfare spiritually, physically and socially". The meaning contained in this law is that the responsibilities of parents and family are the main components in the educational process for children. This indicates that a great role of parents in educating and maturing the children is highly required (Soemanto \& Haryono, 2018).

\section{METHODS}

This research is a collaborative research carried out by the Department of Communication Sciences, Universitas Negeri Yogyakarta and the Center for Media and Communication Studies, Universiti Kebangsaan Malaysia. This research employs a qualitative method. Utilizing qualitative methods, a thorough understanding and interpretation of the meaning of facts, terms, concepts, and assumptions in the fields which are relevant to the research can be realized. Denzin \& Lincoln (2003) explain, "Qualitative research is a field of inquiry in its own right. It crosscuts disclipines, fields, and subject matter. A complex, interconnected family of terms, concepts, and assumptions surround the term qualitative research". Qualitative research also emphasizes inductive thinking by understanding, interpreting, and reflecting on what the informants said and did (Creswell, 2014).

The research setting is determined purposively by considering the research objectives to examine and analyze the prevention of student delinquency through the application of parenting and sharenting communication processes within the family, both in Indonesia and Malaysia. The informants of this research have competence to provide information about the implementation of family communication, so that they were selected informally which represented parents, teachers, and community leaders from two countries. Because this research was conducted during the Covid-19 pandemic, data collection utilized the focus group discussion (FGD) technique via Zoom meeting platform.

To increase the degree of data validity, the research period is extended and a triangulation technique is applied. Thelong research period can be used to examine data consistency and widen the opportunity for researchers to investigate the existing habits, and compare the FGD data taken from one time to another. Patton (2005) explains, "triangulating data is comparing and cross-checking the consistency of information derived at different times and different means within qualitative methods". The data analysis technique employs an interactive analysis model that includes four steps: data collection, data reduction, data display, conclusion: drawing/verifying (Miles \&Huberman, 1994).

\section{RESULTS AND DISCUSSION}

The important finding of this research is the real experience that is shown by the statements of the informants in parenting and sharenting communication practices. The communication process is carried out by parents to children and teachers to students. More specifically, in this research, the communication process is attempted to prevent delinquency carried out by adolescents and students. The results show that communication between parents and children regarding parenting and sharenting are routine activities performed in daily life. Because it has become a daily activity, parents consider it an obligation. This is in accordance with the explanation of Informant 3 as follows.

... parenting and sharenting are my duty as parents. I try to communicate with children by applying different strategies, direct communication or using cellphones. I always try to be opened when my children face a problem. My expectations as a parent are simple, namely, my children go to 
school diligently, follows the advice of teachers and parents, do not perform wrongdoings, and able to protect himself from negative influences (Informant 3, 22 October 2020).

Communication techniques between parents and children in the context of parenting and giving advice (sharenting) for the prevention of delinquency in children or adolescents are carried out gradually, including the application of informative techniques where parents provide information tochildren aboutgoodness which can direct children for better future. This informative technique is also used by parents to inform children about some examples of juvenile delinquency that have the potential to harm the future of the adolescent. When informative techniques are not sufficient for preventing juvenile delinquency, persuasive techniques are employed.

Persuasive communication technique is perceived as an appropriate technique selected by parents in parenting and sharenting activities. Parents as persuaders convey messages subtly to persuade children as persuadee. Parents position themselves as friends who communicate with full of affection and love. Manap, Hoesni, \& Hamzah (2018) state "love is one indicator of happy and functional family. Without love, the family climate becomes dull and empty". Tubbs \& Moss (2001) state that in persuasive communication, communicators or persuaders show exactly how communicants will get benefits. Alavi \& Mahbob (2017) suggest that persuasive communication needs to generate enthusiasm, motivation, self-confidence, and ensure that children are always careful to avoid delinquency.

The aims of persuasive communication carried out by parents and teachers are to influence the children or students to have good behavior and prevent juvenile delinquency. Communicators convey messages to communicants in order that they understand and do as desired by the communicators. The low ability of parents as communicators causes a lack of credibility in the eyes of children. The results show that someparentsthought that theywere nolonger able to prevent their children from juvenile delinquency. Parent's care and advice are not ignored by children. Therefore, parents feel that they unable to provide solutions to problems faced by their children. The view of informant 1 illustrates this fact.

... The problems faced by teenagers are very complex such as problems related to schools, peers and societies. I honestly admit that my ability to care and advise my children do support them. I often feel confused because I don't have an idea as a solution to children's problems. I keep trying to do so in order that, in the future, I will be able to better understand the problems and provide solutions that can be accepted by my children. (Informant 1, October 22, 2020).

Parenting and sharenting communication which utilizes persuasive techniques requirestheskillsofaparentasacommunicator in stimulating children through messages and advice that can be accepted by children. Hovland, Janis, and Kelley (1983) explain that persuasive communication is a process where communicators deliver and convey a stimulus that is aimed at changing the attitudes of others and is carried out in persuasive ways. To increase the effectiveness of communication, the communicators play a strategic role as stated by Effendy (1986) that in persuasive communication, the existence of a communicator or persuader is put at risks. Persuader must have high ethos. Ethos refers to a person's self-value which is a combination of cognition, affection, and conation. Krech, Crutchfield, \& Ballachey (1972) believe that the effectiveness of persuasive communication really depends on how the communicators can be accepted by the communicant. In detail, Soemirat \& Suryana (2016) describe that a persuader who has a high ethos is indicated by the readiness to perform persuasion, seriousness, sincerity, self-confidence, calm, friendliness, and simplicity.

Parenting and sharenting communication carried out with persuasive 
techniques is sometimes not effective in certain cases. Even though adolescence have been persuaded gently, those who have involved in various delinquent acts sometimes do not get the communication effects as expected by the communicators. In this case, it is necessary to apply coercive communication techniques. This communication techniques is performed using force to persuade even sanctions are given. Coercive techniques are chosen, when informative and persuasive techniques are not effective. The opinion of informant 2 demonstrates the application of this coercive technique.

... I am a teacher at schools as well as a parent for my children at home. When there are children who are indicated to have committed delinquency and they have been advised but they neglect it; they should be admonished with coercion and sanctions. As a counseling teacher, I used to give punishments at school, for instance, students are to clean the garden. Even in the past, many teachers hit naughty students with rattan. The purpose of giving sanctions and punishment is to make the juvenile delinquency prevention program more effective.

\section{(Informant 2, October 22, 2020).}

Parents use coercive communication in order that their children can be motivated to do what the parents recommend. Usually, parentsusecoercivecommunicationtocontrol and punish their children if they don't obey their orders. This coercive communication is not fully used all the time. In other words, parents have their own stages when they have to utilize coercive communication with their children. Parents do this purely for no negative purposes. Parents always want the best for their children. The majority of parent expects their children to be smart children and avoid cases of delinquency.

Kamaruddin (2017) states that, in coercive communication, communicators need to have personality and policies so that punishment and sanctions given to the children or students do not cause psychological trauma for the communicant. Furthermore, Rosiana (2017) reminds that the use of coercive communication techniques should be postponed as long as the child can still be persuaded. The purpose of persuasion and coercion are the same, namely to change attitudes, opinions or behavior. The difference is that persuasion is carried out in a subtle, flexible, humanistic way while coercion contains sanctions or threats. The effects of performing a coercion is a change in attitude, view, or behavior with a feeling of being forced because coercion is carried out with forces which may cause feelings of displeasure, even hatred, and maybe resentment. Meanwhile, the results of persuasion communication include awareness and willingness.

The results of the data analysis show that there are various attempts to revitalize the functions and roles of parenting and sharenting communication performed by parents and teachers. Revitalization in this research is interpreted as an effort to strengthen parenting and sharenting communication as important and strategic activities in order to prevent juvenile delinquency. The communication process is carried out in the school and family environment.

Revitalizing communication within the family environment is realized in the form of strengthening parental commitment and credibility in the eyes of children. Parents have a role as communicators to convey messages that lead to the development of children's noble character. Viewed from the duration of time, communication within the family has the longest duration compared to schools and communities. Children's behavior patterns are highly influenced by the communication patterns that are practiced in the family on a daily basis.

\section{CONCLUSION}

Based on the research results and discussions, parenting and sharenting communication are strategic forums to guide adolescents to avoid various forms of deviant 
behavior, especially delinquency. Teenagers are a valuable asset for the nation and state. Theyarepotential future leaders of the nation, so they need to be equipped with superior personal capacities in the form of academic abilities and noble character. In parenting and sharenting communication systems, the family environment (home) is the main and first environment for adolescents.

\section{REFERENCES}

Aini, L. N. (2017). Hubungan pola asuh orang tua dengan kenakalan remaja di RW V Kelurahan Sidokare Kecamatan Sidoarjo. Jurnal Keperawatan dan Kebidanan, 6(1). 211-224.

Alavi, K., \& Mahbob, M. H. (2017). Komunikasi berkesan dengan warga emas: Dari perspektif intervensi kerja sosial. Jurnal Komunikasi, Malaysian Journal of Communication, 33(4). 21-37. doi: https://doi.org/10.17576/ JKMJC-2017-3304-02

Aw, S. (2019). The failure of persuasive communication among social workers in mentoring street children. Jurnal Komunikasi: Malaysian Journal of Communication, 35(2). 161175. doi: https://doi.org/10.17576/ JKMJC-2019-3502-10

Aw, S., Hajaroh, M., \& Hastasari, C. (2020, February). Preventing student delinquency through three education center communication. In International Conference on Educational Research and Innovation (ICERI 2019) (pp. 311313). Atlantis Press. doi: https://doi. org/10.2991/assehr.k.200204.059

Blum-Ross, A., \& Livingstone, S. (2017). "Sharenting," parent blogging, and the boundaries of the digital self. Popular Communication, 15(2), 110-125. doi: https://doi.org/10.1080/15405702.2016.1 223300

Choi, G. Y., \& Lewallen, J. (2018). "Say Instagram, Kids!": Examining sharenting and children's digital representations on Instagram. Howard Journal of Communications, 29(2), 144164. doi: https://doi.org/10.108o/106461 75.2017.1327380

Creswell, J. W. (2014). Research design: Qaualitative, quantitative, and mixed methods approaches (4th ed.). London: Sage.

Davis, N. O., \& Carter, A. S. (2008). Parenting stress in mothers and fathers of toddlers with autism spectrum disorders: Associations with child characteristics. Journal of autism and developmental disorders, 38(7), 1278-1291. doi: https:// doi.org/10.1007/s10803-007-0512-Z

Denzin, N. K., \& Lincoln, Y. S. (2003). O involved in the study of social problems. Handbook of social problems: $A$ comparative international perspective, 30.

Effendy, O.U. (1986). Dinamika komunikasi. Bandung: PT Remaja Rosdakarya.

Hovland, C. I., Janis, I. L., \& Kelley, H. H. (1983). Communication and persuasion; Psychological studies of opinion change. Yale University Press.

Krech, D., Crutchfield, R.S., \& Ballachey, E. (1972) Individual in society. McGraw Hill Book Company.

Keen, D., Couzens, D., Muspratt, S., \& Rodger, S. (2010). The effects of a parent-focused intervention for children with a recent diagnosis of autism spectrum disorder on parenting stress and competence. Research in Autism Spectrum Disorders, 4(2), 229-241. doi: https:// doi.org/10.1016/j.rasd.2009.09.009

Klein, V., Becker, I., \& Štulhofer, A. (2018). Parenting, communication about sexuality, and the development of adolescent womens' sexual agency: A longitudinal assessment. Journal of youth and adolescence, 47(7), 14861498. doi: https://doi.org/10.1007/ s10964-018-0873-y

Kurniawan, D. (2018). Komunikasi model laswell dan stimulus-organism- 
response dalam mewujudkan pembelajaran menyenangkan. Jurnal Komunikasi Pendidikan, 2(1), 6o-68. doi: $\quad$ https://doi.org/10.32585/jkp. v2i1.65

Locker, K. O., \& Kienzler, D. S. (2013). Business and administrative communication. McGraw-Hill.

Manaf, A. M. A., Taibi, M., \& Manan, K. A. (2017). Media agenda and publicagenda: A study of issues during the 13th general election. Jurnal Komunikasi: Malaysian Journal of Communication, 33(2). 13-26. doi: https://doi.org/10.17576/ JKMJC-2017-3302-02

Miles, M. B., Huberman, A. M., Huberman, M. A., \& Huberman, M. (1994). Qualitative data analysis: An expanded sourcebook. London: Sage.

Muawanah, L. B. (2012). Kematangan emosi, konsep diri dan kenakalan remaja. Persona: Jurnal Psikologi Indonesia, 1(1). 6-14. doi: https://doi.org/10.30996/ persona.viii.9

Patton, M. Q. (2005). Qualitative research. Encyclopedia of statistics in behavioral science.

Rahmat, J. (2001). Psikologi komunikasi. Bandung: PT. Remaja Rosdakarya.

Rosiana, K. (2017). Teknik komunikasi koersif dinas kesejahteraan sosial dalam menanggulangi gelandangan dan pengemis di Kota Samarinda. eJournal Ilmu Komunikasi, 2017, 5 (4):109-118

Siibak, A., \& Traks, K. (2019). The dark sides of sharenting. Catalan Journal of Communication $\mathcal{E}$ Cultural Studies, 11(1), 115-121. doi: https://doi. org/10.1386/cjcs.11.1.115_1

Sulaiman, I.A. (2013). Model komunikasi formal dan informal dalam proses kegiatan pemberdayaan masyarakat. Jurnal Penelitian Komunikasi. 6(2). 231242.

Sumara, D.S., Humaedi, S., \& Santoso., M. B. (2017). Kenakalan remaja dan penanganannya. Prosiding Penelitian dan Pengabdian kepada Masyarakat, 4(2). 346-347. doi: https://doi. org/10.24198/jppm.v4i2.14393

Tubbs, S. \& Moss, S. (2001). Human communication konteks-konteks komunikasi. diterjemahkan oleh Dedy Mulyana. Bandung: PT Remaja Rosdakarya.

Unayah, N., \& Sabarisman, M. (2016). Fenomena kenakalan remaja dan kriminalitas. Sosio informa, 1(2). 121140. 
Informasi, Volume 50. Nomor 2. 2020 